\title{
The limits of skill-selective immigration policies: Welfare states and the commodification of labour immigrants
}

Journal of European Social Policy 2019, Vol. 29(4) 478-497 (c) The Author(s) 2019

Article reuse guidelines: sagepub.com/journals-permissions DOI: $10.1177 / 0958928718819609$ journals.sagepub.com/home/esp @SAGE

\author{
Melanie Kolbe and Elif Naz Kayran \\ Graduate Institute of International and Development Studies, Switzerland
}

\begin{abstract}
Why do some countries have more skill-selective labour immigration policies than others? Despite general agreement that high-skilled immigrants are economically and socially desirable, some countries extensively select high-skilled from low-skilled labour immigrants, while others do not. While most political economy accounts indicate an explicit connection between relative skill selectivity and welfare states, two different hypotheses emerge regarding the direction of this relationship. The fiscal cost hypothesis puts forward that the tension between welfare state generosity and immigration motivates greater selectivity as states try to reconcile fiscal pressures for closure with continuing needs for immigration. The decommodification hypothesis, in contrast, holds that the capabilities of generous welfare states to decommodify their citizens also decrease rationales to be more skill-selective towards labour immigrants. Developing an original measure of skill selectivity in labour immigration policies for 20 developed democracies from 2000 to 2010, we test these two hypotheses. Our results indicate that differences in decommodification levels appear to be substantively and negatively associated with differences in skill selectivity levels, while changes in welfare spending over time, particularly among high-spending countries, rather than differences in spending levels, seem to be positively associated with increasing skill selectivity. This suggests potential tensions between the political responses to economic and demographic changes in the form of immigration policy adjustments and the underlying social logic of modern welfare states. The findings contribute not only to the study of high-skilled immigration, but also advance the current research on the tension between immigration and the welfare state.
\end{abstract}

\section{Keywords}

Comparative political economy, high-skilled immigration, labour immigration, migration policy, welfare state

\section{Introduction}

The management of labour immigration ${ }^{1}$ has become one of the key issues of modern industrialized countries. Most European states have turned away from zero-immigration policies that limited labour immigration after the 1970s and have displayed, over the

\section{Corresponding author:}

Melanie Kolbe, Department of International Relations and

Political Science, Graduate Institute of International and

Development Studies, Chemin Eugène-Rigot 2, I2I I Geneva,

Switzerland.

Email: melanie.kolbe@graduateinstitute.ch 
past decade, a strong trend towards skill-selective policies and programmes for third-country national workers that grant different admission and work rights based on educational endowment, different skill sets and occupational experiences (Czaika and Parsons, 2017; Haas et al., 2018; Parsons et al., 2014). There is general agreement among politicians and scholars that high-skilled immigrants ${ }^{2}$ (HSI) are economically and socially more desirable than low-skilled immigrants (LSI) (Triadafilopoulos, 2013), particularly within the context of financial strains imposed on welfare states through domestic demographic challenges and increasing immigration (Chaloff and Lemaitre, 2009). Thus, arguments have been advanced that we are witnessing an increasing convergence towards ever more liberal HSI regulations as states attempt to attract the 'best and the brightest' talents (Lavenex, 2007; Shachar, 2013). In addition, recent public opinion research suggests that greater selectivity is potentially also supported by the broad public, as HSI are consistently preferred over LSI (Helbling and Kriesi, 2014; Naumann et al., 2018; Valentino et al., in press).

Few countries, however, have evenly pursued skill-selective immigration policies (Boeri et al., 2012: 23-35); instead, a strong, cross-national variation prevails among skilled immigration programmes regarding admission criteria and post-entry rights (Cerna, 2016; Chaloff and Lemaitre, 2009; Lowell, 2005). Admission criteria typically encompass labour market tests and/or mandatory job offers as well as primary or secondary points tests ${ }^{3}$ (Czaika and Parsons, 2017). Post-entry rights, either directly specified in relation to admission criteria or indirectly through resulting permits or visas, cover the conditions and scope of labour market mobility, residence status and security, and often comprise regulations on employer portability, length of permit validity, labour market access conditions for spouses and permanent residence eligibility (Cerna, 2016; Lowell, 2005).

Indeed, our original dataset of relative skill selectivity in labour immigration policies from 2000 to 2010 for 20 countries confirms that despite an overall increase in skill-selective policies, there is continuing variation across countries in how extensively they select high-skilled (HS) over low-skilled economic immigrants, that is, whether they treat them differently in regard to admission criteria and post-entry rights. For example, the famous Canadian points system grants those applicants who fulfil valued criteria in regard to education, work experience and language abilities preferential treatment in the form of greater labour market mobility and faster access to permanent residence permits. Individuals who do not qualify under the scheme or enter through other visa or permit routes do not enjoy these privileges. This differentiation is not the case in Sweden, which operates a type of 'one-size-fits-all' track where HSI and LSI face identical admission and post-entry conditions.

Furthermore, countries also differ in their level of selectivity across admission and rights dimensions. For example, the United Kingdom features different admission tracks for different skill levels, but there is little substantial difference regarding post-entry rights for most labour immigrants. The opposite is true in France, where the HS permit differs from regular work permits in post-entry rights but not in admission regulations. Given this diversity in selectivity, this article asks: Why do some countries have more selective labour immigration policies for thirdcountry nationals than others? Furthermore, what is the connection between the relative skill selectivity of labour immigration regimes and welfare states? Based on their spending levels, do states with greater welfare effort attempt to protect themselves by granting more selective admission and post-entry rights to incentivize HS immigration while discouraging low-skilled immigration? Or, based on their institutional logics of egalitarianism and decommodification, do more generous welfare states mediate rationales and pressures for greater relative skill selectivity?

To address these questions, this article discusses and tests two diverging hypotheses, derived from two different sets of literature, regarding the relationship between selective labour immigration policies and welfare states. First, the fiscal cost hypothesis, put forward in the political economy of migration literature, holds that the tension between welfare state spending and immigration motivates greater restrictions for LSI, who are deemed to be net fiscal burdens, and simultaneously a greater 
liberalization for HSI, who are in turn believed to be fiscally beneficial. Thus, the more a welfare state spends, the more likely it is to pursue greater selectivity in its labour immigration policy. Second, the decommodification hypothesis, derived from the comparative welfare state literature, argues that the capabilities of expansive welfare state institutions to actively decommodify their native citizens, that is, to make their livelihoods less dependent on their economic worth, decrease not only the perceived potential labour market threat that contributes to skill selectivity but have also instilled egalitarian and inclusive institutional norms that are less compatible with skill-based discrimination of immigrants. Thus, the more generous a welfare state is, the less likely selectivity in labour immigration policy is.

In testing these two claims, we make two contributions. First, we expand and complement the growing comparative literature on HS immigration by developing an original measure of the relative degree of skill selectivity in third-country labour immigration policies and by analysing the determinants of cross-country differences of skill selectivity in immigration regimes. Second, we advance the current research on the relationship between immigration and the welfare state by arguing that welfare states act not only as a source of fiscal concern over immigration but also as shapers of immigration policy.

Overall, we find robust evidence that differences in skill selectivity are associated with differences in welfare generosity levels but not differences in welfare state spending levels. However, we find evidence that increases in welfare spending over time are related to increases in skill selectivity, particularly in European states. This finding suggests potential tensions between political responses to economic and demographic changes in the form of immigration policy adjustments and the underlying social logic of welfare states.

\section{Theoretical framework}

Is greater welfare provision linked to increasing or decreasing relative skill selectivity in labour immigration policies? HS immigration has received growing attention from labour migration scholars. Although research has examined policy origins and restrictiveness as well as determinants of volume and flows (Boeri et al., 2012; Cerna, 2016; Czaika and Parsons, 2017; Ruhs, 2013; Shachar, 2013; Triadafilopoulos, 2013), we know relatively little about how welfare states are connected to differential immigrant selection policies. First, there has been comparatively little inquiry into variation in skill selectivity, that is, the relative difference in admission and post-entry rights between HSI and LSI. ${ }^{4}$ Second, the theoretical focus has predominantly centred on explaining policy variation as a function of labour market actors and national policy processes (Boräng and Cerna, 2019; Cerna, 2016; Menz, 2011), with little attention paid to welfare state dynamics. Third, most HSI policy studies so far have relied on either small- or medium-N studies (see Cerna, 2016; Ruhs, 2013; Triadafilopoulos, 2013), which often limit comparability across a variety of welfare state arrangements, or have used HS immigration policy as an independent, not as a dependent, variable (see Boeri et al., 2012; Czaika and Parsons, 2017).

As this is the first study to examine how different welfare state dynamics affect skill-selective immigration policies beyond individual preferences towards immigration, we predominantly focus on establishing the purported direction and the presence or absence of the two relationships, rather than testing the exact causal associations. Nevertheless, the hypotheses outlined below provide several plausible explanations for how welfare states are directly or indirectly associated with higher or lower relative skill selectivity in labour immigration policy. While a deeper engagement with these explanations would extend beyond the scope of this work, they suggest important sub-logics that inform theoretical expectations on the directionality and scope of their effect.

\section{The fiscal cost hypothesis}

A sizable body of literature argues that the increasingly centrifugal dynamics of labour immigration management are symptoms of states' attempts to reconcile the need for labour immigration in advanced economies with the contrasting logic of welfare state closure (Schierup et al., 2006). In particular, the 'new progressive dilemma' of immigration suggests 
that this reconciliation will not be possible, as immigration is incompatible with generous welfare benefits in the medium to long run (Goodhart, 2004). The consequences of this tension include, on the one hand, uneven yet noticeable welfare state retrenchment (Hay and Wincott, 2012), and, on the other hand, rising welfare chauvinism among European citizens pressuring for the restriction of immigrant access to welfare (Reeskens and Van Oorschot, 2012; Van der Waal et al., 2013).

A third possible consequence constitutes greater skill selectivity, suggesting that the incentives for greater immigrant selection, in the form of differentiating between HSI and LSI, will be most likely to occur in expensive welfare states, where the pressure to reconcile the logics of openness and closure is assumed to be the greatest (Borjas, 1999; Freeman, 1986; Razin et al., 2011). Most work on the political economy of immigration proposes several reasons for why skill selectivity should be positively associated with overall welfare spending.

The first reason suggests that political actors in more expensive welfare states will be compelled to select according to skill as a consequence of fiscal pressures. Since Freeman (1986), scholars have argued that high welfare state effort, especially in combination with universal eligibility, would be eroded by increasing immigration, which blurs fiscally necessary distinctions between members and non-members. Welfare states that combine costly public benefits with relatively few access restrictions would act as powerful 'magnets' for particularly low-skilled and poor immigrants (Borjas, 1999; Nannestad, 2007). To avoid an 'Americanization' of European welfare state systems (i.e. a retrenchment of welfare benefits across the board), it is argued that only the significant curtailment of particularly lowincome immigrants would ameliorate this welfare state dilemma (Freeman, 1986).

At the same time, greater selectivity is not merely an outcome of avoiding 'undesirable' immigration but is also a result of the explicit need for qualified immigration in consequence of ageing populations and labour shortages in key sectors such as information and communication technology, biomedicine or healthcare (Cerna, 2016; Schierup et al., 2006). Furthermore, HS immigration has been argued to sustain welfare states due to higher employability and lower rates of reliance on social assistance as well as higher contributions to social insurance and taxation schemes (Facchini and Mayda, 2012; Ruhs, 2013: 41; Schierup et al., 2006). Thus, demand for and supply of different skills among foreign workers and their anticipated fiscal impact determine how much access and rights are granted to them by destination country governments to either incentivize or disincentivize their immigration (Ruhs, 2013). If the (anticipated) fiscal cost argument is correct, then support for skill selectivity is higher in welfare states with higher levels of social spending, as increasing immigration carries implications for taxation and budget deficits.

A second reason suggests that it is not directly fiscal pressures but public opinion and implied subsequent voting behaviour that drives greater selectivity in labour immigration policy. It is argued that in the context of anticipated costs associated with immigration, citizens may be opposed to LSI who, through their projected income or need for social services, are deemed to drive up taxes. Instead, natives prefer HSI, who are expected to contribute more in taxes and simultaneously be less likely to become dependent upon welfare (Facchini and Mayda, 2009, 2012; Hanson and Chiquiar, 2005; Hanson et al., 2007). In particular, rich natives, who are the most affected by tax hikes (Facchini and Mayda, 2009; Helbling and Kriesi, 2014), and individuals in high fiscal-exposure states, that is, generous welfare states that also experience high rates of immigration (Hainmueller and Hiscox, 2010 or where immigrants are net recipients rather than net contributors of social benefits (Naumann et al., 2018), should be in favour of greater skill selectivity.

The fiscal argument for greater selectivity is often contrasted with labour market competition arguments, which suggest that low-skilled natives would prefer HSI, as these immigrants would not directly compete with them over scarce jobs but would instead be skill complementary, while HS natives would fear direct job competition and decreasing wages, thus opposing HSI (Freeman and Kessler, 2008; Mayda, 2006). While some evidence by Malhotra et al. (2013) suggests that HS natives are indeed opposed to HSI, particularly in sectors where 
foreign labour competition is high, several recent experimental studies have found little evidence for the labour market competition hypothesis and instead have presented robust evidence for the fiscal cost hypothesis (Hainmueller and Hiscox, 2010; Helbling and Kriesi, 2014; Naumann et al., 2018).

In sum, the real or anticipated tension between the level of welfare spending and immigration is what motivates greater skill selectivity in welfare states with higher rates of welfare effort. Thus, the fiscal cost hypothesis can be summarized as follows: the greater welfare state spending is, the more likely states are to display greater relative skill selectivity in labour immigration policy, that is, to significantly differentiate between HSI and LSI.

\section{The decommodification hypothesis}

Although an often invoked argument, the empirical evidence for the welfare magnet hypothesis is mixed: while some studies find evidence for it (Bruecker et al., 2002; Giorgi and Pellizzari, 2009; Razin et al., 2011), other studies fail to do so (Giuletti et al., 2013; Levine and Zimmerman, 1999; Pedersen et al., 2008). Furthermore, a number of studies tend to ignore potential endogeneity, as states may increase spending in response to incoming immigrants or may modify eligibility criteria for welfare access to discourage immigration (Giuletti et al., 2013). Furthermore, while recent experimental studies have provided new evidence for the fiscal cost argument (Helbling and Kriesi, 2014; Naumann et al., 2018), they do so only for individual-level preferences and cannot attest to whether and to what extent these preferences translate into policy output.

More importantly, welfare state effects tend to be operationalized in terms of social expenditure, a strategy that does not sufficiently account for institutional differences in welfare state types (Arts and Gelissen, 2002: 143-5; Esping-Andersen, 1999: 75), which may mediate immigration-induced fiscal pressures. For example, in conservative welfare states where social entitlements are based on contributory insurance schemes rather than on taxation, spending pressures are ameliorated, as immigrants naturally receive lower benefits than natives since their length and amount of contribution tend to be lower
(Sainsbury, 2006: 235). In contrast, in need-based liberal welfare states, immigrants are more readily identifiable as benefits recipients, and the low-tax environment makes increased taxation publicly visible (Facchini and Mayda, 2012; Hanson et al., 2007; Helbling and Kriesi, 2014: 597). Conversely, the nondiscriminatory, universal and public good-oriented allocation of taxes in social-democratic states does not visibly single out immigrants as beneficiaries (Sainsbury, 2006: 238), and greater fiscal spending in already high-taxation states translates into small, comparatively less publicly noticeable increases (Helbling and Kriesi, 2014: 597). Thus, immigrants may be viewed as fiscal burdens in some institutional contexts more so than in others.

Further, the comparative welfare state literature suggests that variation in welfare state institutions shapes attitudes towards immigration (Crepaz and Damron, 2009; Reeskens and Van Oorschot, 2012; Van der Waal et al., 2013). However, in regard to policy, this literature has predominantly focused on the inclusionary or exclusionary consequences of welfare states on immigrant integration and welfare rights (Römer, 2017; Sainsbury, 2006), that is, immigrant policy, and less on immigration policy, which is concerned with how immigrant entry is regulated (Hammar, 1985). ${ }^{5}$ Nonetheless, the welfare state literature may be instructive in regard to immigration policy as well. In particular, generous welfare states with greater institutional capacity to decommodify their citizens may decrease not only potential labour market concerns over immigration that motivate skill selectivity but have also instilled egalitarian and inclusive institutional norms that are difficult to reconcile with skill-based legal discrimination. As such, the comparative welfare state literature suggests a negative relationship between welfare generosity and skill-selective immigration policy.

The first argument presupposes that welfare states' ability to decommodify native workers - that is, to make their livelihood less dependent on the price of their wage labour and the value of their skills (EspingAndersen, 1990: 90) - decreases the degree to which immigrants are generally feared as labour competition by native citizens, thereby reducing the political pressures exerted through the electorate or labour unions to implement more selective policies. As 
labour market considerations rest on assumptions about incoming immigrants as possible competition to the similarly skilled native workforce (Facchini and Mayda, 2012), the graver consequences of unemployment vary according to a state's redistributive capacities, such as income replacement. Through generous benefits, higher redistribution and comprehensive social protection, universal welfare states decommodify their workers to the greatest extent, thereby attenuating the consequences of job loss. In contrast, liberal welfare states with means-tested benefits, a lower degree of redistribution and rudimentary social protection ameliorate the consequences of job loss the least (Esping-Andersen, 1999: 85-6). Indeed, perceptions of sociotropic labour market threat have been found to be less pronounced in more decommodifying generous welfare states (Crepaz and Damron, 2009).

Furthermore, LSI pose a greater labour market threat to native low-skilled workers than do HSI to native HS workers, who are often protected from foreign competition through higher required language proficiency and formal skill levels (Helbling and Kriesi, 2014: 601-3). Thus, labour market competition concerns are realistically stronger among lowskilled workers, leading to increasing incentives to implement restrictions for LSI. Yet, the same is not necessarily true for HSI, and in consequence dissimilar regulations for HSI and LSI ensue. In contrast, a greater degree of generosity would lower incentives to apply restrictions specifically for LSI, thereby leading instead to similar provisions in LSI and HSI regulations. Thus, selective immigration policy should be more prevalent in less decommodifying states where potential labour market competition poses greater social risks for low-skilled native workers.

A second reason concerns welfare state institutions' varying ability to induce norms of solidarity, inclusiveness and egalitarianism, which make policies that stratify and select immigrants by skill either less or more complementary to the respective welfare state logic. Welfare states that strongly redistribute have the power to lower social stratification, as they reduce income inequality (Korpi and Palme, 1998) and increase overall equality in outcome (Pierson, 2001). Lower levels of social stratification are strongly linked to norms of egalitarianism (Esping-Andersen, 1999: 79-80) as well as solidarity and social trust (Crepaz, 2008), which have been found to significantly decrease negative attitudes towards newcomers (Crepaz and Damron, 2009; Larsen, 2008; Reeskens and Van Oorschot, 2012) and to increase states' likelihood of accepting the 'least economically desirable' immigrants: refugees (Boräng, 2015).

The presence of institutional norms and expectations of egalitarianism also affects the degree to which immigration 'entry' categories can be used as determinants of the level of rights and privileges granted to immigrants, effectively creating a 'hierarchical differentiation' of immigrants (Sainsbury, 2006: 230). For example, social-democratic welfare states' logic of inclusive membership has created norms of equality (Crepaz and Damron, 2009; Sainsbury, 2006: 240) that may strongly circumscribe the extent to which policymakers are willing to discriminate among labour immigrants according to skill, whereas in conservative welfare regimes, in which the logic of redistributive institutions emphasizes differential incorporation and status preservation (Esping-Andersen, 1999: 81-3), greater leeway for contrasting policies towards immigrants should exist. The strongest and most complementary selectivity should be observable in liberal welfare states, which emphasize norms of self-reliance and market mechanisms such as supply and demand, and in which strong stratification is more socially acceptable (Esping-Andersen, 1999: 75; McGovern, 2012: 488-9; Larsen, 2008: 150-1), thereby making skill selection a logical component of labour immigration policies.

In sum, the degree to which immigration policy selectivity can be more discriminatory or more egalitarian is complementary to the institutional logic and the generosity of the national welfare state institutions. Thus, the decommodification hypothesis can be summarized as follows: the more generous a welfare state is, the less likely it is to display greater skill selectivity in its labour immigration policy, that is, to not significantly differentiate between HSI and LSI.

\section{Spending versus redistribution: two dimensions of the welfare state variation}

The fiscal cost hypothesis suggests a positive relationship between welfare states and skill selectivity, while the decommodification hypothesis proposes a 
negative relationship. A review of both claims reveals, however, two different underlying dynamics that relate to two separate dimensions of welfare states. The fiscal cost hypothesis centres on arguments about different levels and changes in levels of social expenditure, while the decommodification hypothesis focuses on arguments about the effect of generous redistributive institutions. This is an important distinction, as expenditure itself tells us neither about the level of commitment to social citizenship nor the solidarity underlying the redistributive system; while states can have similar spending levels, their redistributive capacity may differ widely (Esping-Andersen, 1990: 19-20). Redistributive institutions, in contrast, capture the programmatic aspects of welfare states, such as whether redistribution is realized through means-tested programmes of social insurance or need-independent appraisals of equal access. Other than pure assessments of expenditure, differences in welfare institutions thus significantly determine social stratification and social solidarity norms and serve as a more precise indicator of welfare state generosity (Crepaz and Damron, 2009; Esping-Andersen, 1990).

Furthermore, as noted above, both claims identify differences in selectivity as a function of different levels of either spending or redistribution. However, the fiscal cost hypothesis also makes a case for a temporal effect: as spending increases, it should be associated with increases in selectivity. No such temporal effect, however, is put forward under the decommodification hypothesis. While this omission does not exclude the possibility that decreases in decommodification could hypothetically be connected to greater skill selectivity, the slow and uneven nature of institutional change in welfare states (Hay and Wincott, 2012) leads us to expect, at least in the short run, a dominant cross-sectional rather than temporal relationship with skill selectivity.

\section{Alternative explanations}

Several alternative explanations and controls should be considered as well. A first set of political factors concerns party and interest group politics. Ideological cleavages and party politics have been argued to affect the issue framing of immigration and hence the salience of immigration policy (Green-Pedersen and Krogstrup, 2008; Odmalm, 2011). In particular, parties of the left have been identified as more immigration-friendly, less restrictive and less human capital-oriented (Lahav, 1997). Furthermore, traditional interest group explanations of immigration control see unions as protective of the domestic workforce against the risks of wage dumping and labour competition (Penninx and Roosblad, 2000). ${ }^{6}$ While the policy preferences of unions are highly heterogeneous across cases (see, for example, Donnelly, 2016; Watts, 2002), unions can nonetheless be expected to be more concerned with the creeping commodification of labour and thus more likely to oppose greater skill-selective measures. Moreover, employer associations have been found crucial in supporting or lobbying for HS migration policies in order to attract qualified and competitive human capital (Cerna, 2016; Menz, 2011) and thus should be expected to be associated with greater skill selectivity.

A second set of likely determinants includes demographic and policy factors. One can expect that in order to more actively reduce or manage existing or potential inflows of immigrants, higher shares of immigrants already residing in a given host-country are related to increasing selectivity. Similarly, greater shares of highly educated native workers may decrease selectivity, as the need to recruit abroad is lessened, and HS natives oppose labour competition from skilled foreign workers more strongly (Mayda, 2006). In addition, we also control for overall labour immigration policy restrictiveness, as the dependent variable captures solely the extent to which HSI and LSI regulations diverge, and not whether that difference occurs in liberal or restrictive contexts. However, we expect theoretically that labour immigration restrictiveness limits the extent to which HSI regulations can be substantially more liberal than LSI regulations, thereby reducing the extent of relative skill selectivity. Thus, overall labour immigration restrictiveness serves as an important control for a potentially spurious relationship between welfare state measures and our dependent variable, which is driven by policy restrictiveness rather than net skill selectivity.

A last set of controls involves structural factors such as high levels of unemployment and low levels of gross domestic product (GDP), which may suggest 
a decreased need for overall labour immigration and an increased pressure on fiscal resources. These factors should thus lead to higher skill selectivity. In addition, we control for the rigidity of labour markets, as the presence of employment protection regulations on hiring, certification or wage-setting and so on, potentially limit the legal capacity of policies to attach a premium to hiring skilled labour (McGovern, 2012). Finally, while no binding European labour immigration regime has been put in place that is enforceable over national policy-making processes (Boswell and Geddes, 2011: 93), European Union (EU) regulations can constrain restrictions on immigration policy and therefore EU membership needs to be considered as a control.

\section{Data and methods}

This study employs a cross-sectional analysis of 20 democracies from 2000 to 2010, including 15 European states (Austria, Belgium, Denmark, Finland, France, Germany, Ireland, Italy, Netherlands, Norway, Portugal, Spain, Sweden, Switzerland and the United Kingdom) and 5 non-European ones (United States, Canada, Australia, New Zealand, Japan). Our sample selection is driven by theoretical and practical reasons. First, theoretically, these 20 cases embody the variety of established welfare states. Furthermore, all included countries have adopted third-country national programmes or visas for HSI, except for Switzerland and Sweden. Switzerland was included because, as of 2008, the requirements for the work and residence permit for third-country nationals by definition applies almost exclusively to HSI. Sweden was included as policy changes in 2008 led to greater flexibility in hiring, particularly of HS workers (Boräng and Cerna, 2019).

In terms of geographical coverage, we further excluded other countries such as South Korea, Singapore, Estonia or Slovenia that have also developed skilled immigration programmes, as these countries have, until recently, either been predominantly emigration states (e.g. South Korea), have not yet experienced serious labour immigrant flows (e.g. Estonia or Slovenia) or have no long-standing welfare state traditions (e.g. Singapore or South Korea), which we, however, take as undergirding our assumptions about the decommodification hypothesis. Regarding the temporal coverage, practically, the availability of comparable data on the necessary time points and variables limits the scope of our sample. In particular, one of our main indicators of interest, decommodification, as measured by the Comparative Welfare Entitlements Dataset (CWED v.2), is only available until 2010. Considering this limitation and the fact that HSI policies are a relatively recent development in Europe, we are thus confining our analysis to the time points between 2000 and 2010 .

\section{Dependent variable}

While recently several high-quality datasets of quantitative immigration policy evaluations, such as Immigration Policies in Comparison (IMPIC) (Helbling et al., 2017) and Determinants of International Migration (DEMIG) (2015), have become available, to the best of our knowledge, no dataset allows the scoring of relative selectivity between HSI and LSI policy regulations. ${ }^{7}$ We therefore developed an index measure of relative skill selectivity for third-country labour immigration policy for 20 countries from 2000 to 2010 by consulting laws, legal texts, expert information and secondary literature, ${ }^{8}$ to determine whether and to what extent HSI and non-HSI programmes hold diverging regulations.

We assessed differences between HS and lowskilled labour immigration policies using seven items coded for every country at given year points. We used the three most common items pertaining to differences in admission regulations: labour market tests, job offer requirements and points tests (Parsons et al., 2014). We do not include items such as the use of quotas and shortage or occupational lists, however. Quotas limit the number of possible work permits granted in a given year to control the overall number of foreign workers in national labour markets and are hence often applied to all incoming streams of labour migrants. ${ }^{9}$ Shortage or occupational lists, in contrast, seek to fill particular labour market demand, which can, depending on the sector in which these are attested, include low- as well as high-skilled labour categories. Thus, while certainly a means of managing labour migration, quantitative restrictions and 
shortage lists reflect the overall restrictiveness of immigration regulations rather than skill selectivity.

Furthermore, drawing from previous studies on HSI policies (Cerna, 2016; Lowell, 2005), we coded several associated post-entry rights that cover the conditions and scope of labour market mobility, residence status and security: employer mobility, spousal labour market access, work-permit length and regulations regarding access to permanent residence. These post-entry rights, we argue, are part of immigration policy, as they are essential to an immigrant's ability to sustain a living and fulfil conditions to legally remain in the country. This sets them analytically and empirically apart from other rights stemming from domestic integration and citizenship policies, which, in contrast, shape the conditions of full membership (Bjerre et al., 2015: 561-2). We coded each of the seven items as binary variables: a score of 0 was given if there was no substantial difference in policy provisions, while a score of 1 was given if there was. ${ }^{10}$

We used multiple correspondence analysis (MCA) on a Burt matrix with adjustment to the principal inertias to construct a latent categorical variable composed of the relationships between the seven binary variables. Consistency and scale reliability measures suggest that the items indeed strongly indicate a latent variable of relative skill selectivity of labour immigration policies. ${ }^{11}$ We inverted the scale of the resulting row-score coordinate predictions to indicate more selectivity for higher values and normalized the scale to vary from 0 to 1 . While the admission and rights dimensions share a latent concept, one may nonetheless expect variation in how much relative selectivity is present in either dimension. To explore this matter, we further constructed two separate index variables using the same MCA solution method for each dimension, respectively. Results indicate similar scale reliability for each dimensional index. To ensure that empirical results are not driven by the index construction method, we corroborated results by using several different MCA solutions and by constructing a simple additive scale index. Finally, we constructed an alternative index based on an ordinal instead of a binary coding strategy to capture countries where multiple HSI tracks exist, with potentially different skill selectivity. The results, however, remained robust regardless of index construction or coding strategy.

\section{Independent variables}

In order to capture the redistributive dimension of welfare state generosity, we use the welfare state decommodification index from the CWED (Scruggs et al., 2017). This index is commonly used to capture the institutional differences in welfare state generosity (Boräng, 2015; Crepaz and Damron, 2009; Scruggs et al., 2017), as it is built on systematic evaluations of social policy (unemployment, sickness and pension, etc.) and protection measures. Welfare generosity scores range in our sample from 20.7 (Australia in 2009) to 43.9 (Norway in 2010), with higher values reflecting greater generosity $(\mu=32.2$, $\mathrm{SD}=6.41$ ). We do not include a measure reflecting the classical welfare state typology here, as it has been suggested that it is too static and overlooks several different mixed regimes, such as Mediterranean or former Communist types (Arts and Gelissen, 2002). In order to address the effort dimension of welfare states, we use total social expenditure as a percentage ofGDP $(\mu=21.6, \mathrm{SD}=4.19)$ (Organisation for Economic Co-operation and Development (OECD), 2018), which ranges in our sample between 12.6percent (Ireland in 2000) and 30.7 percent (France in 2010). To further capture not only spending but fiscal 'pressure', we also control for budget deficit, that is, the difference between government spending and revenue, as a percentage of GDP (OECD, 2018). In addition, we include an interaction term between immigrant stock and social expenditure to better capture the concept of fiscal exposure to immigration, that is, the presence of costly public benefits and high levels of immigration (Hainmueller and Hiscox, 2010; Naumann et al., in press).

To gauge political determinants, we included the ideological composition of governments using the Party Government Dataset (Seki and Williams, 2014) and the share of left party seats in the parliament using the Comparative Welfare States Dataset (Brady et al., 2014). Furthermore, we captured union power through two different measures: union density as percentage of trade union members among all paid employees (OECD, 2018), and Visser's (2016) measure for 
union's role in wage bargaining, where (0) indicates no sector agreements, (1) ability to negotiate agreements at the sector level and (2) additional veto power over company agreements. While there is, to our knowledge, currently no encompassing measure of the strength of employer associations, we account for their potential effect by using the share of high-tech industries (percent of high-tech industrial production in manufactured exports) (The World Bank, 2018) as a proxy, as particular knowledge-intensive industries have been argued to have a strong interest in HSI (Bauer and Kunze, 2004).

To account for demographic and policy factors, we included controls for the permanent immigrant inflows and immigrant stocks as share percentages of total population (OECD, 2018). Furthermore, we included the share of tertiary-educated population (OECD, 2018) and IMPIC's measure of the overall restrictiveness of labour immigration policy (Helbling et al., 2017). Finally, to control for structural factors, we added macroeconomic indicators such as log GDP per capita and unemployment rate (in \%) (OECD, 2018; The World Bank, 2018) and strictness of employment protection legislation (EPL) in individual and collective dismissals for regular contracts (OECD, 2018). Last, we include a dummy for $E U$ membership. Descriptive statistics for all variables used can be found in Supplemental Appendix Table A1.

\section{Estimation strategy}

An autoregressive (AR) (1) feasible generalized least squares (FGLS) estimation with year fixed effects was used to assess the effect of decommodification and social expenditure on the relative skill selectivity index. This approach was selected for both theoretical and methodological reasons. Theoretically, we are interested in cross-national variation over variation within states across time. Methodologically, decommodification constitutes a slow-moving independent variable, that is, there is little within-country variation over time, while relative skill selectivity, the dependent variable, is similarly limited in its within-unit variability. This limitation means that the inclusion of country fixed effects would be problematic, as it potentially discards much of the information and leads to imprecise estimates and large standard errors for the variable in question (Barro, 2012). Given the small sample size (20 units and 11 observations) and presence of sluggish variables, we thus follow the advice by Clark and Linzer (2015) to employ a random effects specification in order to appropriately gauge the effect of welfare generosity. ${ }^{12}$ As preliminary tests indicated the presence of unit-specific autocorrelation and heteroscedasticity in our data, we used an FGLS model, which is a close-to-random-effects estimation that can correct for both problems.

The fiscal hypothesis, however, also raised theoretical expectations for a possible temporal effect of social expenditure: as social expenditure increases over time, regardless of the absolute level of expenditure, states become more skill selective. We therefore employ additional estimations of year and country fixed effects specifically to test this possible association. ${ }^{13}$ For sensitivity and robustness tests, we employed other estimation strategies, used various lag structures on our independent and dependent variables and employed jack-knife resampling to check for the sensitivity of sample dependence. Through diagnostic tests, we confirmed the absence of multicollinearity in our estimations and accounted for potential non-stationarity, given the limited variation in our dependent variable. ${ }^{14}$ As additional controls, we further included family and asylum policy restrictiveness ${ }^{15}$ as well as alternative measures for political variables; however, neither returned statistically significant results and hence were not included in the main models. All additional estimations for robustness and sensitivity tests are available upon request.

\section{Results}

\section{Descriptive findings}

Figure 1 presents the levels and trends of relative skill selectivity, welfare generosity and social expenditure in 20 countries for the years 2000-2010. The scale on the right presents the values of the skillselectivity index, where higher values indicate greater relative skill selectivity. The scale on the lefthand side refers to the levels of welfare generosity, as captured by the decommodification measure, and social expenditure (as share of GDP). Overall, a discernible common trend is that most European countries implemented HSI policies some time between 2005 


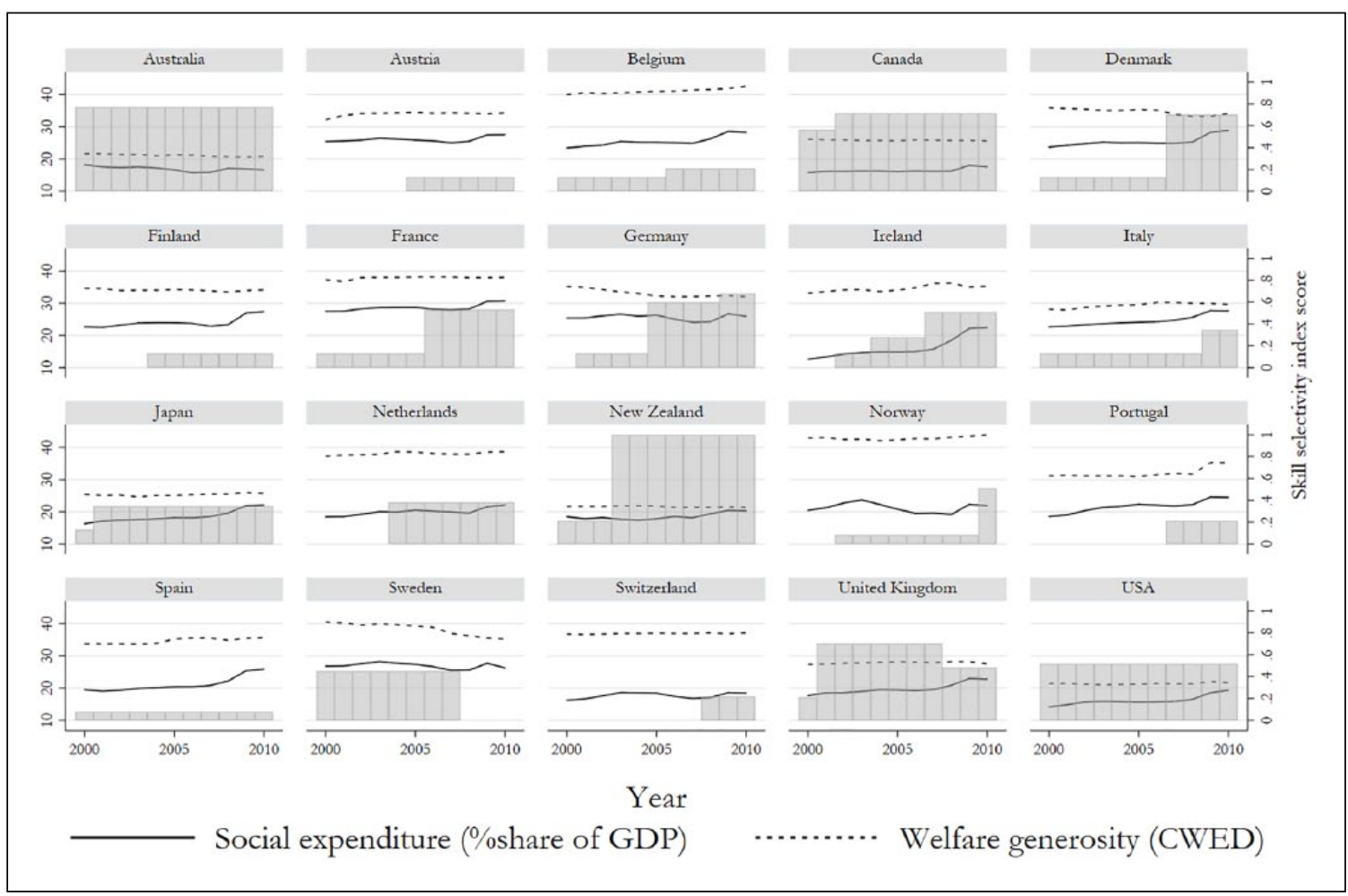

Figure I. Skill selectivity index scores for labour immigration policies, welfare generosity and social expenditure patterns, 2000-20I0.

and 2008, apart from frontrunners such as the United Kingdom (2002) and Denmark (2002) and late developers such as Norway (2010). ${ }^{16}$ Interestingly, most of the states that implemented HS immigration policies early on, such as Denmark and the United Kingdom (until 2008), also have the most selective provisions among European countries by employing points systems.

Relatively stable and higher levels of selectivity are common among settler countries such as Canada, Australia, New Zealand and the United States, which introduced their programmes between the late 1960s and early 1990s but also repeatedly reformed them in later years. ${ }^{17}$ The over-time trend indicates greater selectivity among almost all European countries in the sample, although to varying degrees. Notably, Sweden's score decreases after 2008, when it liberalized labour immigration policy across the board, no longer applying differential rules for LSI and HSI or for short- and long-term foreign workers (Berg and
Spehar, 2013: 143). Similarly, the United Kingdom's score slightly decreased after 2008, when it introduced a new points-test system that suspended and removed their main HS tier and included changes to labour market test and job offer regulations, overall restricting labour immigration policy (DEMIG, 2015). Last, what is not immediately visible from this figure is that several countries such as Canada, Australia and New Zealand have supplemented long-term labour immigration programmes focused on attracting human capital with temporary, labour shortagedriven programmes.

Turning to social expenditure and decommodification, we can note several things. First, comparing the over-time average standard deviation and range, all countries display a lower variance in decommodification (mean $\mathrm{SD}=0.4$ ) than social expenditure (mean $\mathrm{SD}=0.5$ ), except for Germany and Sweden, which show a clear decreasing trend in decommodification $(\mathrm{SD}=1.22$ and 1.98). The opposite is true if we 


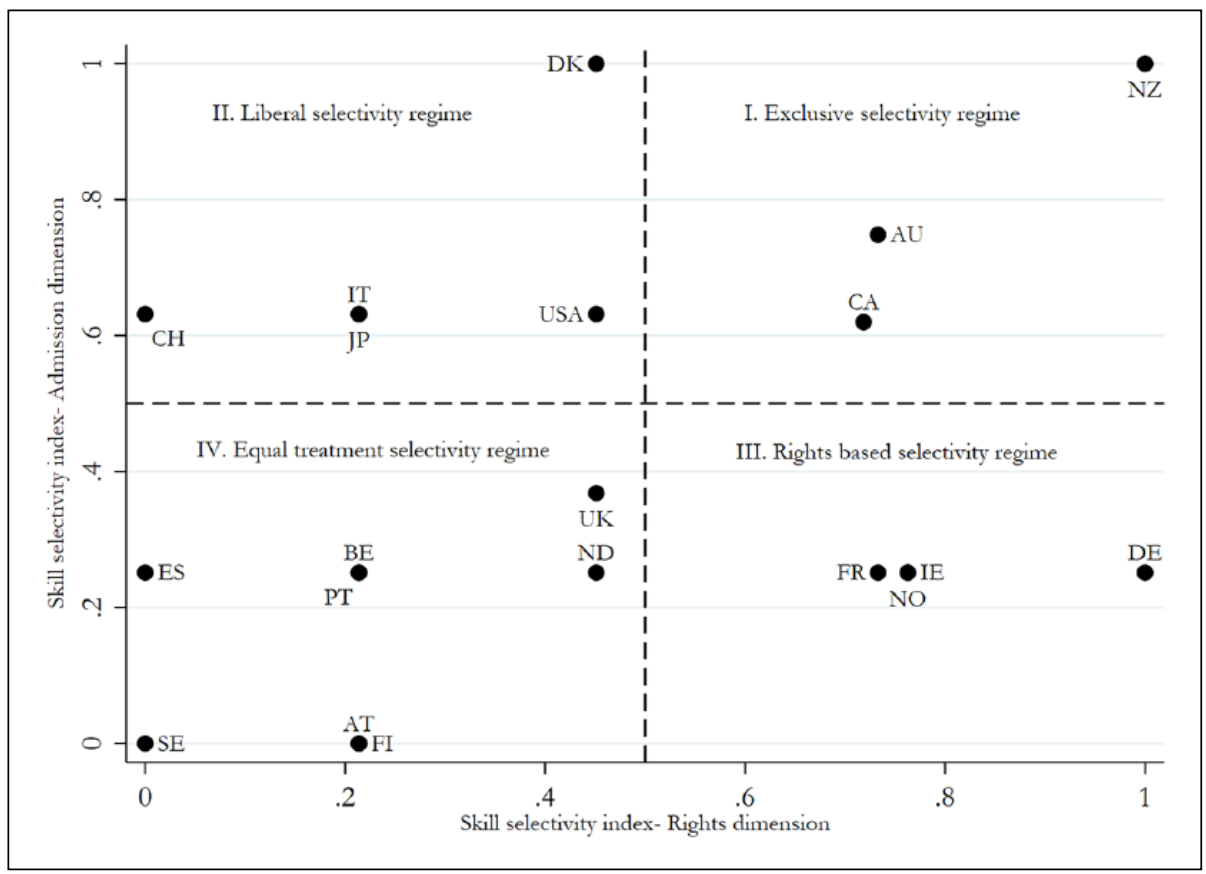

Figure 2. Bivariate scatterplot of selectivity indices of post-entry and admission rights dimensions in 2010 .

compare the same average by year across countries, revealing that variation in decommodification (mean $\mathrm{SD}=6.58$ ) is higher than in social expenditure (mean $\mathrm{SD}=4.37$ ). However, we generally observe an increase in social expenditure over time in all countries in the sample.

Second, and perhaps unsurprisingly, when levels are compared, settler states and the United Kingdom combine lower social expenditure and decommodification levels with higher relative skill selectivity levels. This finding prompts the question as to what extent both indicators capture different but related dimensions of welfare state generosity, as was argued in the theory section. While they are indeed moderately positively correlated (Pearson's R 0.5417), tests for multicollinearity confirmed that the inter-association is negligible. Thus, we are confident that we have indeed captured two distinct dimensions of welfare states.

\section{Variation in selectivity regimes}

While in the beginning of the 2000s, most non-settler states did not feature skill-selective policies, by
2010, we can identify four separate clusters based on the cut-off point of 0.5 in the admission and rights dimension. Figure 2 below presents the separate country scores on admissions and post-entry rights indices per country in 2010. A first cluster, termed the exclusive selectivity regime, comprises states that display higher levels of relative skill selectivity both in admission and post-entry rights, and all employ points systems. While not included in the temporal scope of this study, Austria's introduction of a labour immigration points system would place it as of 2011 in this cluster as well, close to Canada and Australia. Noteworthy is that Denmark, while also employing a points system, does not offer different post-entry rights to the same extent as the other countries.

Hence, we observe a second cluster, the liberal selectivity regime, which comprises countries that tend to stipulate different admissions rules for HSI but do not differentiate substantially in post-entry rights. Denmark's relative closeness to the first cluster may be attributed to their front runner position in HSI policy, indicating a greater interest in and commitment to skill selectivity, yet, along with the United States, also an unwillingness to offer greater post-entry rights. 
This reluctance may potentially be due to greater recent political contention around immigration regardless of skill in all countries in this cluster. The same is true for the United Kingdom pre-2008, which would have also fallen in this cluster, but which also decided to restrict entry regulations for HSI, placing it by 2010 in the equal treatment cluster.

Third, we find the rights-based selectivity regime, where countries like France and Germany tend to offer different post-entry rights for HSI than for LSI but do not substantially differentiate between the two in admission regulations. Last, a final cluster, termed the equal treatment selectivity regime, is represented by countries that only minimally differentiate between labour immigrant workers in admission and post-entry regulations. A typical case for this regime cluster is Belgium, which does not offer a specific HSI track, but highly qualified immigrants who apply under the general work-permit scheme may be exempted from labour market tests and receive longer temporary permits than do low-skilled applicants. Here, we again observe border cases, such as the Netherlands and Ireland, which feature more post-entry rights than the rest of the countries in this cluster but also have more market-oriented economies that may motivate preferential post-entry rights to attract and retain qualified immigrants.

\section{Empirical findings}

Turning to our two hypotheses on variation in skillselective labour immigration policies, Table 1 presents our multivariate estimations with control variables and alternative model specifications. In order to compare coefficients across variables, we present z-score standardized coefficients. Models 1 to 3 present the results of our main model specifications using an FGLS method, correcting for panel autocorrelation and heteroscedasticity, as well as year fixed effects. In Model 1 and Model 2, we include decommodification and social expenditure separately and account for both welfare state dimensions simultaneously in Model 3. Model 4 includes an additional control for budget deficit to further approximate fiscal pressure. Model 5 includes an interaction term between immigrant stock and social expenditure to capture fiscal exposure with more precision. Finally, Model 6 examines only the covariates' effect on European countries.

Generally, we notice that decommodification is negatively associated with skill selectivity and thus operates in the expected direction. However, the direction of social expenditure's association is not consistent and conforms to the expected positive effect on skill selectivity only once we include budget deficit as an additional control. The standardized coefficients further reveal that decommodification has substantively the largest effect size on skill selectivity with the exception of the dummies for union bargaining power. In Model 4, where we include all relevant variables except for the interaction, a standard-deviation increase in decommodification is associated with a 0.12 decrease in skill selectivity at the 0.01 level of significance. This relationship remains robust across most additional tests and sensitivity analyses, including multiple imputations to account for missing observations for New Zealand and Japan.

In contrast, the association of social expenditure is not statistically significant across Models $1-5$. In Model 5, the interaction of social expenditure is added to more precisely measure fiscal exposure; however, we find no significant relationship here either. Our results did not change when we instead interacted social expenditure with annual inflow of immigrants or net migration. While social expenditure performed better in lagged independent variable models, particularly on $\mathrm{t}-1$, its effect was not robustly significant across most additional tests and sensitivity analyses.

Social expenditure is, however, significantly associated with increasing skill selectivity in the European sample, Model 6. A standard-deviation increase is related to a 0.08 increase in relative skill selectivity in our index. In contrast, higher decommodification levels were not associated with lower skill selectivity in the European sample. We attribute this difference from the full sample (Model 4) to three reasons. First, the European sample excludes almost all liberal welfare states with market-oriented economies, except for the United Kingdom and Ireland. This truncation affects the decommodification indicator to a greater degree than the social expenditure measure, which retains 
Table I. FGLS AR (I) models with year fixed effects predicting skill selectivity, 2000-20I0.

\begin{tabular}{|c|c|c|c|c|c|c|}
\hline Variables & Model (I) & Model (2) & Model (3) & Model (4) & Model (5) & Model (6) EU sample \\
\hline Decommodification & $\begin{array}{l}-0.08^{t} \\
(0.044)\end{array}$ & & $\begin{array}{l}-0.09 * \\
(0.043)\end{array}$ & $\begin{array}{r}-0.12 * * \\
(0.038)\end{array}$ & $\begin{array}{l}-0.08^{t} \\
(0.044)\end{array}$ & $\begin{array}{l}0.03 \\
(0.044)\end{array}$ \\
\hline $\begin{array}{l}\text { Social expenditure } \\
\text { (\% share of GDP) }\end{array}$ & & $\begin{array}{l}-0.01 \\
(0.037)\end{array}$ & $\begin{array}{l}-0.01 \\
(0.037)\end{array}$ & $\begin{array}{l}0.02 \\
(0.037)\end{array}$ & $\begin{array}{l}-0.01 \\
(0.039)\end{array}$ & $\begin{array}{l}0.08^{*} \\
(0.04 I)\end{array}$ \\
\hline Budget deficit & & & & $\begin{array}{l}0.02 \\
(0.014)\end{array}$ & $\begin{array}{l}0.02 \\
(0.014)\end{array}$ & $\begin{array}{l}0.02 \\
(0.017)\end{array}$ \\
\hline Government ideology & $\begin{array}{l}-0.01 \\
(0.008)\end{array}$ & $\begin{array}{l}-0.01 \\
(0.010)\end{array}$ & $\begin{array}{l}-0.01 \\
(0.009)\end{array}$ & $\begin{array}{l}-0.01 \\
(0.009)\end{array}$ & $\begin{array}{l}-0.01 \\
(0.008)\end{array}$ & $\begin{array}{l}-0.00 \\
(0.014)\end{array}$ \\
\hline $\begin{array}{l}\text { Share of left seats in } \\
\text { parliament }\end{array}$ & $\begin{array}{l}0.01 \\
(0.026)\end{array}$ & $\begin{array}{l}0.05^{\mathrm{t}} \\
(0.027)\end{array}$ & $\begin{array}{l}0.02 \\
(0.026)\end{array}$ & $\begin{array}{l}0.02 \\
(0.026)\end{array}$ & $\begin{array}{l}0.02 \\
(0.026)\end{array}$ & $\begin{array}{l}0.03 \\
(0.036)\end{array}$ \\
\hline Union density & $\begin{array}{l}0.09 * \\
(0.042)\end{array}$ & $\begin{array}{l}0.03 \\
(0.028)\end{array}$ & $\begin{array}{l}0.09^{*} \\
(0.039)\end{array}$ & $\begin{array}{l}0.07^{*} \\
(0.034)\end{array}$ & $\begin{array}{l}0.09 * \\
(0.043)\end{array}$ & $\begin{array}{l}-0.02 \\
(0.028)\end{array}$ \\
\hline $\begin{array}{l}\text { Employment protection } \\
\text { legislation }\end{array}$ & $\begin{array}{l}0.01 \\
(0.044)\end{array}$ & $\begin{array}{l}-0.03 \\
(0.042)\end{array}$ & $\begin{array}{l}0.00 \\
(0.046)\end{array}$ & $\begin{array}{l}0.00 \\
(0.044)\end{array}$ & $\begin{array}{l}-0.00 \\
(0.046)\end{array}$ & $\begin{array}{l}0.02 \\
(0.046)\end{array}$ \\
\hline \multicolumn{7}{|c|}{ Union bargaining power (baseline: no negotiation) } \\
\hline Sector level negotiation & $\begin{array}{l}-0.22 \\
(0.150)\end{array}$ & $\begin{array}{l}-0.27^{*} \\
(0.112)\end{array}$ & $\begin{array}{l}-0.19 \\
(0.145)\end{array}$ & $\begin{array}{l}-0.26 * \\
(0.132)\end{array}$ & $\begin{array}{l}-0.26 \\
(0.161)\end{array}$ & $\begin{array}{l}-0.46 * * * \\
(0.115)\end{array}$ \\
\hline $\begin{array}{l}\text { Sector level negotiation } \\
\text { w/veto power }\end{array}$ & $\begin{array}{r}-0.4 I^{* *} \\
(0.158)\end{array}$ & $\begin{array}{l}-0.41^{* * * *} \\
(0.125)\end{array}$ & $\begin{array}{l}-0.38^{*} \\
(0.15 \mathrm{I})\end{array}$ & $\begin{array}{r}-0.45 * * \\
(0.140)\end{array}$ & $\begin{array}{r}-0.45 * * \\
(0.167)\end{array}$ & $\begin{array}{l}-0.62 * * * \\
(0.130)\end{array}$ \\
\hline $\begin{array}{l}\text { Immigrant inflows } \\
\text { (\% share population) }\end{array}$ & $\begin{array}{l}-0.00 \\
(0.010)\end{array}$ & $\begin{array}{l}-0.02 \\
(0.012)\end{array}$ & $\begin{array}{l}-0.00 \\
(0.011)\end{array}$ & $\begin{array}{l}-0.01 \\
(0.011)\end{array}$ & $\begin{array}{l}-0.01 \\
(0.011)\end{array}$ & $\begin{array}{l}-0.02 \\
(0.014)\end{array}$ \\
\hline $\begin{array}{l}\text { Immigrant stock } \\
\text { (\% share population) }\end{array}$ & $\begin{array}{l}0.03 \\
(0.042)\end{array}$ & $\begin{array}{l}0.02 \\
(0.034)\end{array}$ & $\begin{array}{l}0.04 \\
(0.040)\end{array}$ & $\begin{array}{l}0.05 \\
(0.036)\end{array}$ & $\begin{array}{l}0.04 \\
(0.043)\end{array}$ & $\begin{array}{l}-0.11 * \\
(0.051)\end{array}$ \\
\hline $\begin{array}{l}\text { Labour migration policy } \\
\text { restrictiveness }\end{array}$ & $\begin{array}{l}-0.05^{* * * *} \\
(0.011)\end{array}$ & $\begin{array}{l}-0.06 * * * * \\
(0.012)\end{array}$ & $\begin{array}{l}-0.05^{* * *} \\
(0.011)\end{array}$ & $\begin{array}{l}-0.05 * * * \\
(0.011)\end{array}$ & $\begin{array}{l}-0.06 * * * \\
(0.012)\end{array}$ & $\begin{array}{l}-0.06 * * * \\
(0.013)\end{array}$ \\
\hline GDP per capita (logged) & $\begin{array}{l}0.02 \\
(0.042)\end{array}$ & $\begin{array}{l}-0.03 \\
(0.042)\end{array}$ & $\begin{array}{l}0.01 \\
(0.043)\end{array}$ & $\begin{array}{l}0.02 \\
(0.042)\end{array}$ & $\begin{array}{l}0.01 \\
(0.043)\end{array}$ & $\begin{array}{l}0.14^{* *} \\
(0.048)\end{array}$ \\
\hline Unemployment rate & $\begin{array}{l}0.01 \\
(0.012)\end{array}$ & $\begin{array}{l}-0.01 \\
(0.014)\end{array}$ & $\begin{array}{l}0.01 \\
(0.012)\end{array}$ & $\begin{array}{l}0.01 \\
(0.013)\end{array}$ & $\begin{array}{l}0.01 \\
(0.012)\end{array}$ & $\begin{array}{l}0.00 \\
(0.015)\end{array}$ \\
\hline $\begin{array}{l}\text { High technology } \\
\text { (\% share exports) }\end{array}$ & $\begin{array}{l}-0.00 \\
(0.022)\end{array}$ & $\begin{array}{l}0.00 \\
(0.022)\end{array}$ & $\begin{array}{l}-0.00 \\
(0.022)\end{array}$ & $\begin{array}{l}-0.01 \\
(0.022)\end{array}$ & $\begin{array}{l}-0.01 \\
(0.023)\end{array}$ & $\begin{array}{l}-0.01 \\
(0.024)\end{array}$ \\
\hline $\begin{array}{l}\text { Tertiary education } \\
\text { (\% share workforce) }\end{array}$ & $\begin{array}{l}-0.00 \\
(0.046)\end{array}$ & $\begin{array}{l}0.04 \\
(0.039)\end{array}$ & $\begin{array}{l}0.01 \\
(0.044)\end{array}$ & $\begin{array}{l}0.03 \\
(0.04 I)\end{array}$ & $\begin{array}{l}-0.00 \\
(0.045)\end{array}$ & $\begin{array}{l}-0.01 \\
(0.048)\end{array}$ \\
\hline EU member (dummy) & $\begin{array}{l}-0.12 \\
(0.162)\end{array}$ & $\begin{array}{l}-0.09 \\
(0.085)\end{array}$ & $\begin{array}{l}-0.07 \\
(0.142)\end{array}$ & $\begin{array}{l}0.05 \\
(0.119)\end{array}$ & $\begin{array}{l}-0.08 \\
(0.157)\end{array}$ & \\
\hline $\begin{array}{l}\text { Social expenditure } x \\
\text { Immigrant stock }\end{array}$ & & & & & $\begin{array}{l}0.02 \\
(0.023)\end{array}$ & \\
\hline Constant & $\begin{array}{l}0.50 * * * \\
(0.114)\end{array}$ & $\begin{array}{l}0.47^{* * * *} \\
(0.113)\end{array}$ & $\begin{array}{l}0.45^{* * *} \\
(0.124)\end{array}$ & $\begin{array}{l}0.43 * * * \\
(0.116)\end{array}$ & $\begin{array}{l}0.48^{* * * *} \\
(0.130)\end{array}$ & $\begin{array}{l}0.58^{* * *} \\
(0.127)\end{array}$ \\
\hline Observations & 179 & 179 & 179 & 179 & 179 & 129 \\
\hline Number of countries & $18^{\mathrm{a}}$ & $18^{\mathrm{a}}$ & $18^{a}$ & $18^{a}$ & $18^{a}$ & $13^{b}$ \\
\hline $\mathrm{Chi}^{2}$ & 114.6 & 202.5 & 136.4 & 187.0 & 125.3 & 128.5 \\
\hline
\end{tabular}

Standardized coefficients are presented, standard errors in parentheses.

FGLS AR (I): Autoregressive feasible, two-step, generalized least squares estimation; EU: European Union; GDP: gross domestic product. ${ }^{\mathrm{N} N e w}$ Zealand and Japan are dropped.

bExcludes Norway and Switzerland.

${ }^{*} \mathrm{p}<0.05$; ${ }^{* *} \mathrm{p}<0.0$ I; *** $\mathrm{p}<0.00$ I; ${ }^{\mathrm{t}} \mathrm{p}<0.1$. 
most of its variation, and explains why decommodification is no longer a significant predictor. Second, the majority of countries that have introduced new HSI legislation throughout the observation period are, in fact, located in Europe. Third, all countries in the European sample experienced increases in social expenditure over time, which was on average higher $(\mathrm{SD}=3.75)$ than in the settler states and Japan $(\mathrm{SD}=1.57)$ over the same period. Furthermore, out of the 12 countries in the sample, 8 are above the median of social expenditure across the entire observation period, indicating that this development affected particularly high-expenditure welfare states.

While this evidence suggests that social expenditure levels per se are not associated with skill selectivity the way decommodification levels are, the fiscal cost hypothesis also implies that increasing social expenditures can be expected to lead to increasing skill selectivity. Evidence for this assumption is provided by a year and country fixed estimation of our models (see Supplemental Appendix Table A2), which allows us to assess the effect of social expenditure variation over time. The results reveal that a one standard-deviation increase in social expenditure is associated with a 0.17 increase in social expenditure, significant at the 0.01 level, while decommodification is non-significant. In conjunction with the descriptive results, this result supports that while more generous welfare states are less skill-selective overall, increasing social expenditure has unfolded an opposite dynamic over time.

In addition to testing the two main hypotheses, we also found that specific determinants had substantive effects on relative skill selectivity. For the full sample, we find that while increasing veto power of unions in wage bargaining is associated with a decrease in selectivity, union density is associated with more selectivity and was not significant in the European sub-sample. This result may indicate that cross-national differences in how well interest groups are formally integrated in decision-making effectively influences policy-outcomes.

Other political variables had no robust significant effect on our skill selectivity measure. Not surprisingly, overall labour immigration policy restrictiveness significantly decreases skill selectivity in all model specifications, indicating that general restrictiveness leaves less scope to offer more liberal or generous provisions to a particular labour immigrant group. Furthermore, immigrant stock is only significantly associated with less relative skill selectivity in the EU sample, indicating a negative relationship rather than a positive one as expected.

Last, we also estimated our models separately for admission and post-entry rights dimension, respectively (Supplemental Appendix Tables A4 and A5). The results of the post-entry rights selectivity analysis resemble those of the overall selectivity analysis, however, the coefficient size for decommodification increases noticeably while the association is significant at the 0.01 level. In contrast, the admissions selectivity analysis shows that decommodification is a negligible determinant, while social expenditure appears to have now a negative relationship with selectivity, as long as budget deficit is not controlled for. Instead, admissions selectivity is more reliably predicted by other determinants: overall greater levels of labour migration policy restrictiveness, domestic employment protection and GDP per capita as well as EU membership are all associated with lower levels of skill selectivity.

\section{Conclusion}

This article tested two different hypotheses of how welfare states affect skill selectivity in labour immigration policies. The fiscal cost hypothesis predicted that particularly expensive welfare states experience fiscal strains due to increasing immigration, which in turn leads to growing fiscal and public opinion pressures to be skill-selective. In contrast, the decommodification hypothesis argued that generous welfare state institutions decrease pressures and normative justifications for skill selectivity. Developing an original measure of relative skill selectivity in labour immigration policies between HS and low-skilled tracks for 20 industrialized democracies from 2000 to 2010, we tested these two hypotheses employing a series of FGLS estimations with year fixed effects.

Overall, the multivariate findings provide support for the decommodification hypothesis, as higher generosity levels are robustly associated with less skill selectivity. Evidence for the fiscal cost hypothesis suggests that changes in spending levels, particularly among high-spending countries, rather than differences in spending levels, seem to be positively 
associated with increasing skill selectivity. We attribute support for both hypotheses to the fact that welfare effort and welfare generosity are two different aspects of welfare states that unfold contrasting dynamics. While European states, on average, are markedly less selective and display greater crossnational variation than settler states, the findings point to a potential tension between political responses to economic and demographic changes in the form of immigration policy adjustments and the underlying protective and social capability of welfare states that moderate these attempts. It may well be that generous European states will not be able to pursue skill selectivity - as a function of increasing fiscal pressures - to the same extent as less generous ones or settler nations without provoking political frictions with institutions and norms of decommodification and social equality.

This study contributes to current debates in the literature on labour immigration policy in two ways. First, the article adds to the comparative literature on labour immigration studies (Boswell and Geddes, 2011; Ruhs, 2013) by examining the relative crosscountry differences in LSI and HSI policy provisions and its determinants. We further add to the current empirical projects on quantifying immigration policies (DEMIG, 2015; Helbling et al., 2017; Ruhs, 2013) by creating an original dataset of relative skill selectivity in labour immigration regimes, which proposes a measure that focuses not on policy restrictiveness but instead on relative differences in policy regulations for different labour immigrant groups.

Second, the findings contribute to the current political economy of migration debates about the tension between welfare states and immigration, which implies that, among other adaptation strategies such as welfare state retrenchment (Freeman, 1986; Freeman and Kessler, 2008) and immigrant welfare access restrictions (Reeskens and Van Oorschot, 2012; Van der Waal et al., 2013), skillselective immigration policies can potentially ameliorate the 'progressive dilemma' of advanced welfare states as well. While this view may have some purchase, as the over-time trends indicate, our analysis also demonstrated that there is reason to believe that the institutional generosity of welfare states may limit the potential for greater discrimination of labour immigrants based on skill. Thus, we argue that welfare states are not just a source of fiscal concern over immigration but also act as policy constraints. Simultaneously, we also add to the comparative welfare state literature, which has so far predominantly focused on how welfare states mediate anti-immigrant attitudes and immigrant rights (Crepaz and Damron, 2009; Römer, 2017; Sainsbury, 2006), by showing that welfare states affect not only immigrant policy but also immigration policy.

While this article represents a first attempt to analyse skilled immigration policy in a large-N context, it is also limited in its scope. As this article has put forth an institutionalist argument, it does not speak to the agency of political actors and the underlying processes that drive their welfare state actions. Similarly, it has only tested the general hypothesized relationships, rather than the precise causal mechanisms possibly driving them. Using micro-foundational evidence, process-tracing or expert interviews, future work needs to more directly investigate the political dynamics and actors involved. A further limitation of the article is its focus on third-country national provisions in labour immigration policy, which excludes supranational or international mobility agreements, such as in the EU or North American Free Trade Agreement (NAFTA). Nonetheless, it is fruitful to also investigate if comparable dynamics are at play in the context of intra-regional free movement regulations.

Furthermore, our data capture only aggregate entry and post-entry rights and regulations between LSI and HSI policies. More fine-grained data that also capture variation in multiple short- and longterm programmes is needed to help uncover more intricate differences and similarities in labour immigration provisions. In addition, due to data limitations, the temporal scope of our study is capped at the year 2010. However, recent developments in both welfare state adjustments and immigration policymaking show that a temporal extension to recently implemented policies post-2010 should be explored in future work. It is likely that social expenditure effects become even more pronounced when a larger time-frame is analysed. Similarly, more precise measures of fiscal exposure for a number of years are 
needed for a comprehensive evaluation of the fiscal cost hypothesis.

Taken together, however, we believe that our results have provided first evidence that variation in skill selectivity in third-country labour immigration policy also depends on the configuration and dynamics of modern welfare states, suggesting that highly skilled immigration policy has become another avenue in which the management and sustainability of modern immigration and welfare states has gained prominence.

\section{Acknowledgements}

The authors would like to thank Jeanette Money, Beatrice Eugster and David Sylvan for their valuable feedback on this article, as well as the three anonymous reviewers for their helpful comments and suggestions. Earlier versions of this article were presented at the 2016 American Political Science Association (APSA) Annual Meeting and at the 2017 Swiss Political Science Association Annual Conference.

\section{Funding}

The author(s) received no financial support for the research, authorship and/or publication of this article.

\section{Supplemental material}

Supplemental material for this article is available online.

\section{Notes}

1. The term 'labour immigration' here refers to all regular, economically motivated immigration inflows of third-country nationals. It excludes free movement of persons within the four freedoms of the European Union (EU) and other free movement areas.

2. The term 'high-skilled immigrant' can differ in its detailed scope across states, depending on how they define their scheme, but a common conceptual definition covers the International Standard Classification of Occupations (ISCO) categories 1 to 3 , and matches, by and large, individuals with tertiary education or corresponding experience and specialization (Parsons et al., 2014; Ruhs, 2013).

3. Points tests are an admission instrument which determine immigrants' eligibility for entry under one or several immigration tracks by stipulating specific numerical thresholds to be achieved by gaining a certain number of points for specific human capital characteristics, for example, for education, experience, age.
4. For an exception, see Ruhs (2013). However, he only compares restrictiveness across skill programmes, not how much rights differ in relative terms.

5. But see Boräng (2015) for effects on forced migration admission.

6. Organized labour has been intimately linked to the strength of the welfare state. However, union preferences towards immigration can be rather heterogeneous and are thus treated separately from welfare state arrangements.

7. DEMIG only offers measures of changes in levels of restrictiveness, not overall levels of restrictiveness, while IMPIC, at the time of this publication, does not offer a skill-disaggregated index of policy restrictiveness. Thus, neither index allowed us to construct relative skill selectivity. Nonetheless, we triangulated our conceptualizations, data and coding decisions using these datasets.

8. For all countries, we used primary sources and legal texts available online. In cases where information was not readily accessible, we relied on the resources gathered by European Commission's EU Immigration Portal and triangulated this information with reliable country reports from European University Institute's Migration Policy Centre and European Migration Network (EMN) (full list of primary sources is available upon request).

9. While some countries like Estonia and Italy have indeed expanded their quotas for skilled workers, this change, however, did not entail differential admission regulations or post-entry rights and thus suggests decreasing restrictiveness towards high-skilled immigrants (HSI) but not greater selectivity. See EMN (2013).

10. To ensure inter-coder reliability, the two co-authors have coded the policies separately. The coders overlapped in about 80 percent of the code assignments. The disagreement cases were harmonized after discussion and re-review of the documents.

11. The multiple correspondence analysis (MCA) with Burt matrix and adjustments explains at least 87.82 percent of the total inertia in just the first dimension. Further coincidence analysis results using principal components analysis (PCA) and correspondence analysis (CA) methods ( 0.95 density level) and the use of Cronbach's alpha (0.76 scale reliability) corroborate this result.

12. The Hausman test results point to a significant difference in the estimates across the two specifications for most models. However, the root mean square errors (RMSEs), which are the standard errors of the model's error, for the fixed effects $(0.11)$ and random 
effects $(\sim 0.15)$ specifications of all models are well below the acceptable range of bias $(<0.3)$ (see Clark and Linzer, 2015) and do not diverge greatly from each other. This indicates that the random effects estimator performs only slightly worse than the fixed effects estimator.

13. Results for the fixed effects estimations are included in the Supplemental Appendix Table A2.

14. To test for non-stationarity, we conducted a series of panel unit root tests such as Fisher-type augmented Dicky-Fueller tests and the Levin-Lin-Chu test using 1- and 3-year-lag structures. The results confirm the lack of non-stationarity in our dependent variable and that unit roots are not present across all panels. We used lagged dependent and independent variable model estimations to rule out spurious correlations in our findings.

15. See Supplemental Appendix Table A3.

16. Austria introduced a points system in 2011, called the Red-White-Red Card, but it was not included in our analysis as it is beyond the temporal coverage of the dataset.

17. However, these reforms only adjusted existing instruments, not the relative level of skill selectivity (see Hawthorne, 2008).

\section{References}

Arts, W. and Gelissen, J. (2002) 'Three Worlds of Welfare Capitalism or More? A State-Of Report', Journal of European Social Policy 12(2): 137-58.

Barro, R.J. (2012) 'Convergence and Modernization Revisited', NBER Working Paper no 18295. Cambridge, MA: National Bureau of Economic Research.

Bauer, T.K. and Kunze, A. (2004) 'The Demand for High-Skilled Workers and Immigration Policy', IZA Discussion Paper, Bonn, available at https:// pdfs.semanticscholar.org $/ 9 \mathrm{fbf} / \mathrm{c} 0192 \mathrm{cc} 2 \mathrm{c} 3 \mathrm{f}-$ b847737129aab25825c63579a.pdf.

Berg, L. and Spehar, A. (2013) 'Swimming against the Tide: Why Sweden Supports Increased Labour Mobility within and from outside the EU', Policy Studies 34(2): 142-61.

Bjerre, L., Helbling, M., Römer, F. and Zobel, M. (2015) 'Conceptualizing and Measuring Immigration Policies: A Comparative Perspective', International Migration Review 49(3): 555-83.

Boeri, T., Brucker, H., Docquier, F. and Rapoport, H. (2012) Brain Drain and Brain Gain: The Global Competition to Attract Highly-Skilled Migrants. Oxford: Oxford University Press.
Boräng, F. (2015) 'Large-Scale Solidarity? Effects of Welfare State Institutions on the Admission of Forced Migrants', European Journal of Political Research 54(2): 216-31.

Boräng, F. and Cerna, L. (2019) 'Constrained Politics: Labour Market Actors Political Parties Swedish Labour Immigration Policy', Government and Opposition 54(1): 121-144.

Borjas, G.J. (1999) 'Immigration and Welfare Magnets', Journal of Labor Economics 17(4): 607-37.

Boswell, C. and Geddes, A. (2011) Migration and Mobility in the European Union. Basingstoke: Palgrave Macmillan.

Brady, D., Huber, E. and Stephens, J.D. (2014) Comparative Welfare States in the 21st Century Dataset (CWSD). Chapel Hill, NC: University of North Carolina.

Bruecker, H., Epstein, G.S., McCormick, B., Saint-Paul, G., Venturini, A. and Zimmermann, K. (2002) 'Managing Migration in the European Welfare State', in T. Boeri, G.H. Hanson and B. McCormick (eds) Immigration Policy and the Welfare System, pp. 1168. Oxford: Oxford University Press.

Cerna, L. (2016) Immigration Policies and the Global Competition for Talent. London: Palgrave Macmillan.

Chaloff, J. and Lemaitre, G. (2009) 'Managing HighlySkilled Labour Migration: A Comparative Analysis of Migration Policies and Challenges in OECD Countries', OECD Social, Employment and Migration Working Papers, OECD, Paris.

Clark, T.S. and Linzer, D.A. (2015) 'Should I Use Fixed or Random Effects', Political Science Research and Methods 3(2): 399-408.

Crepaz, M. (2008) Trust Beyond Borders: Immigration, Identity and the Welfare State in Modern Societies. Ann Arbor, MI: University of Michigan Press.

Crepaz, M. and Damron, R. (2009) 'Constructing Tolerance: How the Welfare State Shapes Attitudes about Immigrants', Comparative Political Studies 42(3): 437-63.

Czaika, M. and Parsons, C.R. (2017) 'The Gravity of High-Skilled Migration Policies', Demography 54(2): 603-30.

DEMIG (2015) DEMIG POLICY Database. Oxford: International Migration Institute, University of Oxford.

Donnelly, M.J. (2016) 'Competition and Solidarity: Union Members and Immigration in Europe', West European Politics 39(4): 688-709.

Esping-Andersen, G. (1990) The Three Worlds of Welfare Capitalism. Princeton, NJ: Princeton University Press. 
Esping-Andersen, G. (1999) Social Foundations of Postindustrial Economies. Oxford: Oxford University Press.

European Migration Network (EMN) (2013) The Application of Quotas in EU Member States as a Measure for Managing Labour Migration from Third Countries. Brussels: EMN.

Facchini, G. and Mayda, A.M. (2009) 'Does the Welfare State Affect Individual Attitudes towards Immigrants? Evidence across Countries', The Review of Economics and Statistics 91(2): 295-314.

Facchini, G. and Mayda, A.M. (2012) 'Individual Attitudes towards Skilled Migration: An Empirical Analysis across Countries', The World Economy 35(2): 183-96.

Freeman, G.P. (1986) 'Migration and the Political Economy of the Welfare State', The Annals of the American Academy of Political and Social Science 485: 51-63.

Freeman, G.P. and Kessler, A.K. (2008) 'Political Economy and Migration Policy', Journal of Ethnic and Migration Studies 34(4): 655-78.

Giorgi, G.D. and Pellizzari, M. (2009) 'Welfare Migration in Europe', Labour Economics 16(4): 353-63.

Giuletti, C., Guzi, M., Kahanec, M. and Zimmermann, K.F. (2013) 'Unemployment Benefits and Immigration: Evidence from the EU', International Journal of Manpower 34(1): 24-38.

Goodhart, D. (2004) 'Too Diverse?', Prospect 95: 30-7.

Green-Pedersen, C. and Krogstrup, J. (2008) 'Immigration as a Political Issue in Denmark and Sweden', European Journal of Political Research 47(5): 610-34.

Haas, H.d., Natter, K. and Vezzoli, S. (2018) 'Growing Restrictiveness or Changing Selection? The Nature and Evolution of Migration Policies', International Migration Review 52: 324-67.

Hainmueller, J. and Hiscox, M.J. (2010) 'Attitidues toward Highly Skilled and Low-Skilled Immigration: Evidence from a Survey Experiment', American Political Science Review 104(1): 61-84.

Hammar, T. (1985) 'Introduction', in T. Hammar (ed.) European Immigration Policy: A Comparative Study, pp. 1-13. Cambridge: Cambridge University Press.

Hanson, G.H. and Chiquiar, D. (2005) 'International Migration, Self-Selection, and the Distribution of Wages: Evidence from Mexico and the United States', Journal of Political Economy 113(2): 239-81.

Hanson, G.H., Scheve, K. and Slaughter, M.J. (2007) 'Public Finance and Individual Preferences over Globalization Strategies', Economics \& Politics 19(1): 1-33.
Hawthorne, L. (2008) 'The Impact of Economic Selection Policy on Labour Market Outcomes for DegreeQualified Migrants in Canada and Australia', IRPP Choices 14(5): 1-50.

Hay, C. and Wincott, D. (2012) The Political Economy of European Welfare Capitalism. London: Palgrave Macmillan.

Helbling, M. and Kriesi, H. (2014) 'Why Citizens Prefer over Low-Skilled Immigrants. Labor Market Competition, Welfare State, and Deservingness', European Sociological Review 30(5): 595-614.

Helbling, M., Bjerre, L., Römer, F. and Zobel, M. (2017) 'Measuring Immigration Policies: The IMPIC Database', European Political Science 16(1): 79-98.

Korpi, W. and Palme, J. (1998) 'The Paradox of Redistribution and Strategies of Equality: Welfare State Institutions, Inequality, and Poverty in the Western Countries', American Sociological Review 63(5): 661-87.

Lahav, G. (1997) 'Ideological and Party Constraints on Immigration Attitudes in Europe', Journal of Common Market Studies 35(3): 377-406.

Larsen, C.A. (2008) 'The Institutional Logic of Welfare Attitudes: How Welfare Regimes Influence Public Support', Comparative Political Studies 41(2): 14568.

Lavenex, S. (2007) 'The Competition State and Highly Skilled Migration', Society 44(2): 32-41.

Levine, P.B. and Zimmerman, D.J. (1999) 'An Empirical Analysis of the Welfare Magnet Debate Using the NLSY', Journal of Population Economics 12(3): 391-409.

Lowell, B.L. (2005) Policies and Regulations for Managing Skilled International Migration for Work (United Nations Expert Group Meeting on International Migration and Development). New York: United Nations Secretariat Population Division Department of Economic and Social Affairs.

McGovern, P. (2012) 'Inequalities in the (De-) Commodification of Labour: Immigration, the Nation State, and Labour Market Stratification', Sociology Compass 6(6): 485-98.

Malhotra, N., Margalit, Y. and Mo, C.H. (2013) 'Economic Explanations for Opposition to Immigration: Distinguishing between Prevalence and Conditional Impact', American Journal of Political Science 57(2): 391-410.

Mayda, A.M. (2006) 'Who Is against Immigration? A Cross-Country Investigation of Individual Attitudes toward Immigrants', The Review of Economics and Statistics 88(3): 510-30. 
Menz, G. (2011) 'Employer Preferences for Labour Migration: Exploring 'Varieties of Capitalism'Based Contextual Conditionality in Germany and the United Kingdom', The British Journal of Politics and International Relations 13(4): 534-50.

Nannestad, P. (2007) 'Immigration and Welfare States: A Survey of 15 Years of Research', European Journal of Political Economy 23: 512-32.

Naumann, E., Stoetzer, L. and Pietrantuono, G. (2018) 'Attitudes towards Highly Skilled and Low Skilled Immigration in Europe: A Survey Experiment in 15 European Countries', European Journal of Political Research 57(4): 1009-30.

Odmalm, P. (2011) 'Political Parties and 'the Immigration Issue': Issue Ownership in Swedish Parliamentary Elections 1991-2010', West European Politics 34(5): 1070-91.

Organisation for Economic Co-operation and Development (OECD) (2018) OECD Stat Database. Paris: OECD.

Parsons, C.R., Rojon, S., Samanani, F. and Wettach, L. (2014) 'Conceptualising International High-Skilled Migration', IMI Working Paper no 104. Oxford: International Migration Institute (IMI).

Pedersen, P.J., Pytlikova, M. and Smith, N. (2008) 'Selection and Network Effects: Migration Flows into OECD Countries 1990-2000', European Economic Review 52(7): 1160-86.

Penninx, R. and Roosblad, J. (2000) Trade Unions, Immigration, and Immigrants in Europe, 1960-1993: A Comparative Study of the Attitudes and Actions of Trade Unions in Seven West European Countries. New York; Oxford: Berghahn Books.

Pierson, P. (2001) 'Post-Industrial Pressures on the Mature Welfare States', in P. Pierson (ed.) The New Politics of Welfare, pp. 80-104. Oxford: Oxford University Press.

Razin, A., Sadka, E. and Suwankiri, B. (2011) Migration and Welfare State: Political-Economy Policy Formation. Cambridge, MA: The MIT Press.

Reeskens, T. and Van Oorschot, W. (2012) 'Disentangling the 'New Liberal Dilemma': On the Relation between General Welfare Redistribution Preferences and Welfare Chauvinism', International Journal of Comparative Sociology 53(2): 120-39.

Römer, F. (2017) 'Generous to All or 'Insiders Only'? The Relationship between Welfare State Generosity and Immigrant Welfare Rights', Journal of European Social Policy 27(2): 173-96.

Ruhs, M. (2013) The Price of Rights: Regulating International Labor Migration. Princeton, NJ: Princeton University Press.
Sainsbury, D. (2006) 'Immigrants' Social Rights in Comparative Perspective: Welfare Regimes, Forms in Immigration and Immigration Policy Regimes', Journal of European Social Policy 16(3): 229-44.

Schierup, C-U., Hansen, P. and Castles, S. (2006) Migration, Citizenship, and the European Welfare State. Oxford: Oxford University Press.

Scruggs, L., Jahn, D. and Kuitto, K. (2017) Comparative Welfare Entitlements Dataset 2 (Version 2017-09). Storrs, CT; Greifswald: University of Connecticut; University of Greifswald.

Seki, K. and Williams, L.K. (2014) 'Updating the Party Government DataSet', Electoral Studies 34: 270-9.

Shachar, A. (2013) 'Talent Matters: Immigration PolicySetting as a Competitive Scramble among Jurisdictions', in T. Triadafilopoulos (ed.) Wanted and Welcome? Policies for Highly Skilled Immigrants in Comparative Perspective, pp. 85-104. New York: Springer.

The World Bank (2018) The World Bank Data Bank. Washington, DC: The World Bank.

Triadafilopoulos, T. (2013) Wanted \& Welcome? Policies for Highly Skilled Immigrants in Comparative Perspective. New York: Springer.

Valentino, N.A., Soroka, S.N., Iyengar, S., Aalberg, T., Duch, R., Fraile, M., et al. (in press) 'Economic and Cultural Drivers of Immigrant Support Worldwide', British Journal of Political Science. Advance online publication. available at: https:// www.cambridge.org/core/journals/british-journalof-politicalscience/article/economic-and-culturaldrivers-of-immigrant-supportworldwide/02BB CF09B063FCD0C252B6D78E748DE8\#fndtninformation

Van der Waal, J., Koster, W.d. and Oorschot, W.v. (2013) 'Three Worlds of Welfare Chauvinism? How Welfare Regimes Affect Support for Welfare Distribution to Immigrants among Europeans', Journal of Comparative Policy Analysis: Research and Practice 15(2): 164-81.

Visser, J. (2016) Institutional Characteristics of Trade Unions, Wage Setting, State Intervention and Social Pacts (ICTWSS) Database, 5.1 edn. Amsterdam: Amsterdam Institute for Advanced Labor Studies (AIAS), University of Amsterdam.

Watts, J.R. (2002) Immigration Policy and the Challenge of Globalization: Unions and Employers in Unlikely Alliance. Ithaca, NY: Cornell University Press. 